\title{
Participation of the Intercostal Nerves to the Innervation of the Diaphragm Muscle in Cavia porcellus
}

\author{
Marcelo Domingues de Faria ${ }^{1}$ Adriana Gradela ${ }^{1}$ Ana Caroline dos Santos ${ }^{2}$ \\ Ítalo Barbosa Lemos Lopes ${ }^{2}$ Vanessa Souza Inoue ${ }^{2}$ Bárbara Conceição Vilas Bôas Marques Brito ${ }^{3}$ \\ 1 Post-Graduate Program in Health and Biological Sciences, \\ Universidade Federal do Vale do São Francisco \\ 2 Veterinary Medicine Course, Universidade Federal do Vale do São Francisco \\ 3 Post-Graduate Program in Health and Biological Sciences, \\ Universidade Federal do Vale do São Francisco \\ Address for correspondence Marcelo Domingues de Faria, PhD, \\ Programa de Pós-Graduação em Ciências da Saúde e Biológicas, \\ Rodovia BR 407, Lote 543, Projeto de Irrigação Nilo Coelho, S/N, \\ 56300000, Petrolina, PE, Brazil \\ (e-mail: marcelo.faria@univasf.edu.br).
}

J Morphol Sci 2019;36:24-27.

\begin{abstract}
Introduction The diaphragm is the leading respiratory muscle. It is innervated mainly by the diaphragmatic nerve, and, in some species, by the delicate fibers of the intercostal nerves. In guinea pigs, there is no description of these anatomic structures that innerve this important muscle. This study aimed to analyze the participation of the intercostal nerves to the innervations of the diaphragm of guinea pigs of both sexes.

Materials and Methods We studied 40 guinea pigs (Cavia porcellus) of both sexes. We fixed and dissected the diaphragm of the specimens used in the experiment to assess the path of the intercostals nerves in both the body antimeres.

Results The diaphragm was innervated by the intercostal nerve pairs 6 through 12 , and, less frequently, by the $8^{\text {th }}$ nerve $(38 / 40=95 \%)$, followed by the $7^{\text {th }}(36 /$ $40=90 \%)$ and subsequently by the $9^{\text {th }}(32 / 40=80 \%)$. The $12^{\text {th }}$ nerve presented the lowest frequency $(2 / 20=10 \%)$ in both genders. All nerve pairs displayed similar occurrence compared with the gender and the antimeric disposition. The only exception was the 9th nerve, which presented a significant variation of the occurrence, both in relation to gender and antimeric disposition. From a statistic point of view, all nerves were independent. We observed no correlation between the gender and their position.

Keywords

- guinea pig

- diaphragmatic muscle

- innervation

Conclusions We shall conclude that the diaphragm of guinea pigs is innervated by the $6^{\text {th }}$ through $12^{\text {th }}$ pairs of intercostal nerves, with the $7^{\text {th }}, 8^{\text {th }}$, and $9^{\text {th }}$ being the primary providers. There is no interference of the variables gender or antimeric disposition on the behavior of the intercostal nerves of guinea pigs as refers to their origin and participation to the innervations of the diaphragm.
\end{abstract}

\section{Introduction}

Breathing is the only form to provide oxygen to human beings and animals. As it enters into the organism, the oxygen combines with most of the nutrients before entering the cells and producing the energy that is crucial for the performance of physiologic processes required for survival. The muscles enrolled in the respiratory process are the diaphragm, the scalene, and the intercostal muscles. ${ }^{1}$ The diaphragm is deemed to be only one and essential respiratory muscle, ${ }^{2}$ contributing from 60 to $80 \%$ of the respiratory process, ${ }^{3}$ as it is the main muscle received

November 9, 2018

accepted

February 11, 2019
DOI https://doi.org/

10.1055/s-0039-1683406. ISSN 2177-0298.
Copyright (e) 2019 by Thieme Revinter

Publicações Ltda, Rio de Janeiro, Brazil
License terms

(c) $(1) \$$ 
involved in the inspiration process. The diaphragm is not only enrolled in the act of breathing. It is also crucial to assist the abdominal muscles during vomiting, coughing, urination, sneezing, defecation, and labor. ${ }^{4}$ Almeida et al $(2008)^{5}$ describe the intercostal nerves, mainly those from the 7 th to the $9^{\text {th }}$, as primary efferent pathways for some of these actions or reflexes.

The diaphragm receives motor nerves mainly, or solely from the phrenic nerves. ${ }^{6-13}$ Even the same, in some species, there is a participation also from branches derived from the intercostal nerves. ${ }^{5,14-19}$ There are 12 pairs of intercostal nerves. They derive from the ventral branches of the thoracic nerves, do not form plexus and distribute to the walls of the thorax and the abdomen. Almost all nerves lie in the intercostal space (therefore they are denominated "intercostal nerves"). The 12th intercostal nerve is named subcostal, as it lies under (behind) the last rib. ${ }^{20}$

Guinea pig (Cavia porcellus) is a primary species for the science. It is frequently used for studies on the anatomy and physiology that shall be applied to the humans and other species. ${ }^{21-23}$ Even with the diaphragm being responsible for such an essential function as breathing, there are no studies on the role of the intercostal nerves to its innervation in guinea pigs.

This study aimed to assess the participation of the intercostal nerves to the innervation of the diaphragm in guinea pigs Cavia porcellus of both genders and to describe the collateral innervation of this organ by the intercostal nerves.

\section{Materials and Methods}

In this study, 40 healthy adult male $(n=20)$ and female $(n=20)$ guinea pigs Cavia porcellus (Linnaeus, 1758) were used. The animals came from the central laboratory animal house of the Universidade Federal do Vale do São Francisco (UNIVASF, in the Portuguese acronym). This study was approved and certified by the ethical committee for the use of animals of the UNIVASF (CEUA, in the Portuguese acronym, protocol number 0012/160512).

The specimens were transported to the laboratory of domestic and wild animal anatomy of the UNIVASF (LAADS,
, in the Portuguese acronym ), where they were euthanized ( $40 \mathrm{mg} / \mathrm{kg}$ of $5 \%$ ketamine; $10 \mathrm{mg} / \mathrm{kg}$ of $2 \%$ xylazine intraperitoneally to induce anesthesia, followed by $5 \mathrm{ml}$ of $10 \%$ potassium chloride, intraperitoneally). As a criterion for the enrollment, the animals should not present any anomaly or pathology in the thoracic or abdominal region.

After the euthanasia of the guinea pigs, the left common carotid artery was cannulated to perfuse a $10 \%$ water solution of formaldehyde using $20 \mathrm{~mL}$ syringes and $25 \times 7$ needles. After this, the anatomic pieces were dipped in $10 \%$ formaldehyde solution for 72 hours to fix the tissues. The costochondral articulations were incised to fold them to the exterior from the fifth rib on, in both antimeres. Every intercostal nerve was dissected. All the ramifications were conserved, especially those directed to the diaphragm. After their identification, the ramifications of the intercostal nerves were photographed and compared, to assess their position in the antimere and the sex of the animal.

Statistical analysis was performed using the Statistical Analysis System (SAS) software (SAS Institute Inc., Cary, NC, USA), considering the chi-square test and phi coefficient, and analyzing the independence between the gender (female, or male) and the position (left or right); the independence level between the position and the intercostal nerves and the occurrence of the participation of these nerves to the innervation of the diaphragm. A 5\% significance level was adopted $(p<0.05)$.

\section{Results}

As described in $\mathbf{- T a b l e ~} \mathbf{1}$, the ramifications derived from the intercostal nerve pairs 6 to 12 innerve the diaphragm of guinea pigs. According to the frequency of occurrence, the intercostal nerves were classified in four groups: A group (average) represented by the nerves 6 and 10; B group (high) represented by the nerves 7,8 , and 9 ; $C$ group (intermediate) represented by the $11^{\text {th }}$ nerve, and $D$ group (low), represented by the nerve 12 . We observed no significant difference among the nerves classified in the same group of occurrences.

Table 1 Frequency and percentage of occurrence of the intercostal nerves in the innervation of the diaphragm of guinea pigs (Cavia porcellus), according to the antimere and the gender-Petrolina (PE), 2018

\begin{tabular}{|c|c|c|c|c|c|c|c|c|c|c|c|c|c|c|}
\hline \multirow{2}{*}{$\begin{array}{l}\text { Nerve } \\
\text { Gender }\end{array}$} & \multicolumn{2}{|l|}{$\mathrm{VI}$} & \multicolumn{2}{|l|}{ VII } & \multicolumn{2}{|l|}{ VIII } & \multicolumn{2}{|l|}{ IX } & \multicolumn{2}{|l|}{$x$} & \multicolumn{2}{|l|}{$\mathrm{XI}$} & \multicolumn{2}{|l|}{ XII } \\
\hline & $R$ & L & $R$ & L & $R$ & L & $R$ & $\mathrm{~L}$ & $R$ & $\mathrm{~L}$ & $R$ & L & $R$ & $\mathrm{~L}$ \\
\hline \multicolumn{15}{|c|}{ Females $(N=20)$} \\
\hline $\mathrm{FR}$ & 12 & 13 & 16 & 18 & 18 & 18 & 17 & 14 & 10 & 11 & 4 & 5 & 1 & 2 \\
\hline$\%$ & 24.5 & 26.5 & 22.9 & 25.7 & 24.3 & 24.3 & 27.0 & 22.2 & 24.4 & 26.8 & 26.7 & 33.3 & 14.3 & 28.6 \\
\hline \multicolumn{15}{|c|}{ Males $(N=20)$} \\
\hline $\mathrm{FR}$ & 11 & 13 & 18 & 18 & 20 & 18 & 17 & 15 & 10 & 10 & 3 & 3 & 2 & 2 \\
\hline$\%$ & 22.4 & 26.5 & 25.7 & 25.7 & 27 & 24.3 & 27.0 & 23.8 & 24.4 & 24.4 & 20 & 20 & 28.5 & 28.5 \\
\hline Total & 23 & 26 & 34 & 36 & 38 & 36 & 34 & 29 & 20 & 21 & 7 & 8 & 3 & 4 \\
\hline$\%$ & 46.9 & 53.1 & 48.6 & 51.4 & 47.4 & 48.6 & 54 & 46 & 48.8 & 51.2 & 46.7 & 53.3 & 42.9 & 57.1 \\
\hline
\end{tabular}

Abbreviations: F, female; FR, frequency; L, left antimere; M, male; R, right antimere.

$\%=$ percentage 
The nerve pairs of the A group, 6 and 10, displayed similar occurrence ( $p 0.05$ ) according to both the gender and the antimeric disposition. Both nerves presented $65 \%$ of occurrence in males, and females.

Nerves pairs of the B group 7, 8, and 9 displayed similar occurrence according to both the gender and the antimeric disposition. The $7^{\text {th }}$ nerve was present in $90 \%(18 / 20)$ of the specimens, both male, and female. The $8^{\text {th }}$ nerve too was present in $90 \%(18 / 20)$ of the females, and $100 \%(20 / 20)$ of the males. The $9^{\text {th }}$ nerve was visible in $85 \%(17 / 20)$ of the females and males. - Fig. 1 shows the innervation of the diaphragm by the $7^{\text {th }}$ intercostal nerve.

The nerve of the C Group, $11^{\text {th }}$, showed a similar occurrence $(p>0.05)$ as concerning the gender and the antimeric disposition, in agreement with the other nerves. Even if the participation of this nerve in the innervation of the diaphragm was not relevant, it was present in 55\% (11/20) of the female, and $50 \%$ of the male subjects.

The nerve of the D Group, $12^{\text {th }}$, showed a similar occurrence $(p>0.05)$ as concerning the gender and the antimeric disposition, in agreement with the other nerves. Its participation to the innervation of the diaphragm was the lowest. It was only present in $10 \%(2 / 20)$ of the female, and male subjects.

The Chi-square test over 0.05 , with a value of 0.82 , corresponding to $8 \%$, and Phi-coefficient of -0.026 statistically confirm the independence and the absence of any correlation between the gender and the position among all the nerves that have been studied.

When analyzing the relationship between gender and the occurrence of the nerves either in the left, or in the right antimere, we observed that in females the occurrence was more frequent $(p>0.05)$ in the left antimere $(51 \%=81 / 159)$, than in the right $(49 \%=78 / 159)$. On the other hand, in males, the occurrence was more common in the right antimere $(51 \%=81 / 160)$ than in the left $(49 \%=79 / 160)$. Among the females, all intercostal nerves except the $8^{\text {th }}$ and $9^{\text {th }}$ were observed more frequently in the left antimere. The $8^{\text {th }}$ nerve displayed the same occurrence in both antimeres and the $9^{\text {th }}$ was more frequently observed in the right antimere. Among the males, the nerves 8 and 9 displayed more frequent occurrence in the right antimere. The nerves 7,10,11, and 12 displayed the same occurrence in both antimeres. The nerve 11 was more frequent in the left antimere than in the right one ( - Table $\mathbf{1}$ ).

\section{Discussion}

The results of this study highlight the importance of the intercostal nerves as main efferent ways for the breathing in guinea pigs, not just as motor fibers. These findings disagree with the results of previous studies, which claimed that the phrenic nerve was the main, and probably the only source of innervation of the diaphragm in some mammalian species. ${ }^{6-13}$ On the other hand, our findings are in agreement with other studies that pointed out the contribution of the intercostal nerves to the innervation of the diaphragm., ${ }^{4,5,14-19}$

We observed the innervation of the diaphragm by the intercostal nerves 6 to 12 , mainly by the $8^{\text {th }}$ nerve. Rosenblueth et al (1961), ${ }^{4}$ even if they observed the participation of the intercostal nerves 4 to 10 , observed that the major intercostal nerve acting in the innervation of the diaphragm was the $8^{\text {th }}$ nerve. In dogs, MELO et al (1999) ${ }^{24}$ observed the innervation of the diaphragm by the intercostal nerve pairs 8 to 12 in $93.54 \%$ of cats and dogs. Faria et al $(2011)^{16}$ observed the central innervation of the diaphragm by the intercostal nerves 9 through 11 , but the possible participation of the nerve fibers from the intercostal nerves 7,8 , and 12 . Oliveira et al $(2001)^{25}$ observed that the diaphragm of hybrids of bovines and zebus received the innervation of the intercostal nerves 7 through 12 in $50 \%$ of the animals; from the intercostal nerves 6 through 12 in $33.3 \%$; from the left antimere of the $6^{\text {th }}$ intercostal nerve in $13.3 \%$ of the animals, and from the right antimere of the $7^{\text {th }}$ nerve in $3.3 \%$ of the animals. Almeida et al $(2008)^{5}$ observed in bovines from the Santa Inês breed, the contribution to the innervation of the diaphragm of the intercostal nerves 8 to 12

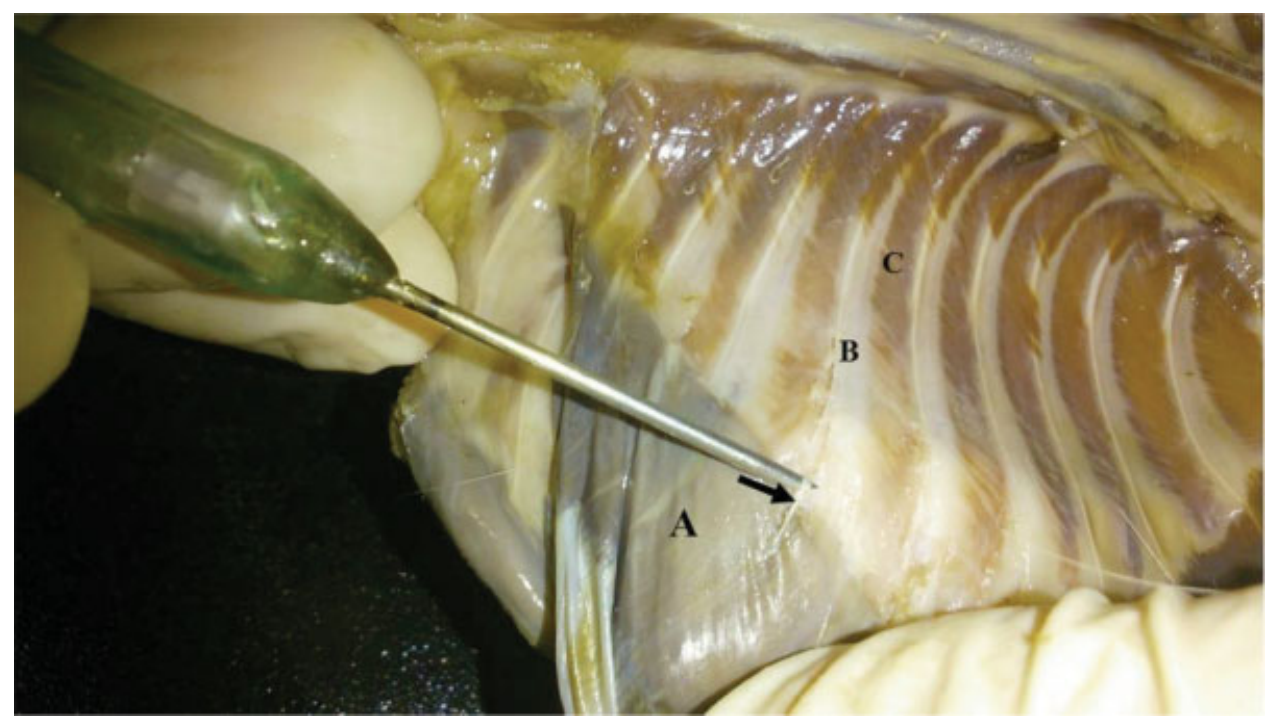

Fig. 1 Photograph highlighting the participation of the VII intercostal nerve (arrow) to the innervation of the diaphragm (A) of guinea pigs (Cavia porcellus). In (B), the seventh rib is visible and in (C), the intercostal muscle-Petrolina (PE), 2018. 
in $63.33 \%$ of the animals, and of the pairs 9 to 12 in $26.68 \%$ of the animals, in both antimeres. In agreement with our results, these authors also did not observe any difference in the participation of the intercostal nerves to the innervation of the diaphragm neither according to the gender nor the antimeric disposition.

In this study, we observed little participation of the intercostal nerve $12(10 \%)$ to the innervation of the diaphragm in both genders, in disagreement with the study of Melo et al (1999), ${ }^{24}$ who observed that the $7^{\text {th }}$ pair of nerves innerved the diaphragm in only $3.22 \%$ of the cases.

\section{Conclusions}

We shall conclude that the diaphragm of guinea pigs is innervated by the $6^{\text {th }}$ through 12 th pairs of intercostal nerves, with the $7^{\text {th }}, 8^{\text {th }}$, and $9^{\text {th }}$ being the primary providers. There is no interference of the variables gender or antimeric disposition on the behavior of the intercostal nerves of guinea pigs as refers to their origin and participation to the innervation of the diaphragm.

\section{Conflicts of Interest}

The authors have no conflicts of interest to report.

\section{References}

1 Druz WS, Sharp JT. Activity of respiratory muscles in upright and recumbent humans. J Appl Physiol 1981;51(06):1552-1561

2 Lessa TB, de Abreu DK, Bertassoli BM, Ambrósio CE. Diaphragm: A vital respiratory muscle in mammals. Ann Anat 2016;205:122-127

3 Shindoh C, Murakami Y, Shishido R, Sasaki K, Nishio T, Miura M. Tulobuterol patch maintains diaphragm muscle contractility for over twenty-four hours in a mouse model of sepsis. Tohoku J Exp Med 2009;218(04):271-278

4 Rosenblueth A, Alanís J, Pilar G. The accessory motor innervation of the diaphragm. Arch Int Physiol Biochim 1961;69:19-25

5 Almeida AEF, Wenceslau CV, Teixeira DG, et al. Morfofisiologia da inervação do diafragma de ovinos. Pesqui Vet Bras 2008;28(09): 399-409

6 Andrei O. Sulle alterazioni anatomiche del diafragma che susseguono adeserei del nervo frênico. Arch. Ital. Cirur. 1928;21:313-328

7 Bertelli D. Distribuzione dei nervi frenice nei diaframma nei mammiferi. Arch Ital Anat Embriol 1933;32(01):110-148

8 Bertelli O. Ricerche sulla morfologia del musculo diafragm a nei mammiferi. Arch. Scient. Med. Vet. v. 19, n.4, p.381-437, 1985
9 Bertelli D. Contributo ala del anatomia del diaframma nei carnivori. Monit. Zool. Ital. 1894;1(9-10):211-215

10 Dyce, K.M.; Sack, W.O.; Wensing, C.J.G. Tratado de Anatomia Veterinária. 3.ed. Guanabara Koogan, Rio de Janeiro, 2004. p.307-308

11 Fontes V. Notes anatomo physiologiques sur l'etude deu muscle diaphragm. Arq Anat Antropol 1934;17(07):34-36

12 Ghoshal NG. Nervos espinhais. In: Getty R (ed.), Anatomia dos Animais Domésticos. 5.ed. Guanabara Koogan: Rio de Janeiro; 1975:1052-1055

13 Zimmerl U. Sistema nervoso. In: BOSSI V., CARADONNA G.B., SPAMPANI G., VARALDI L. \& ZIMMERL U. (ed.), Trattato di Anatomia Veterinária.v.3. Francesco Vallardi, Milano; 1909:228-229

14 Chou Y-L, Davenport PW. Phrenic nerve afferents elicited cord dorsum potential in the cat cervical spinal cord. BMC Physiol 2005;5(01):7

15 Davenport PW, Shannon R, Mercak A, Reep RL, Lindsey BG. Cerebral cortical evoked potentials elicited by cat intercostal muscle mechanoreceptors. J Appl Physiol (1985) 1993;74(02):799-804

16 Faria MD, Seyfert CE, Gagliardo KM, Clébis NK. Participação dos nervos intercostais na inervação do diagragma de gatos Felis Catus, Linnaeus, 1758. Braz J Vet Res Anim Sci 2011;48(04): 315-318

17 MIA A. The innervation of the diaphragm in zebu cattle (Bos indicus). Bangladesh Vet. J. 1973;1:29-32

18 Moura CEB, Albuquerque JFG, Magalhães MS, Silva NBS, Oliveira MF, Papa PC. Análise comparativa da origem do plexo branquial de catetos (Tayassu tajacu). Pesqui Vet Bras 2007;27(09):357362

19 Souza Neto JRN, Branco É, Giese EG, Lima AR. Morphological Characterization of Diaphragm in Common Squirrel Monkey (Saimiri sciureus). An Acad Bras Cienc 2018;90(01):169-178

20 Netter FH Atlas de Anatomia Humana. 2.ed. Porto Alegre: Artmed, 2000. 640p.

21 Gradela A, Nunes AKR, Matos MHT, Franzo VS. FARIA, M.D.; MOREIRA, M.B.;SANTOS, J.M. Descrição morfológica e morfométrica da glândula vesicular de cobaias durante o desenvolvimento pós-natal. Pesqui Vet Bras 2013;33(07):942-948

22 Gradela A, Nunes AKR, Martins LFT, et al. Estudo morfológico e morfométrico da próstata de cobaios (Cavia porcellus, Linnaeus, 1758) durante o desenvolvimento pós-natal. Biotemas 2013a26 (04):221-231

23 Suzuki O, Koura M, Noguchi Y, Takano K, Yamamoto Y, Matsuda J. Optimization of superovulation induction by human menopausal gonadotropin in guinea pigs based on follicular waves and FSHreceptor homologies. Mol Reprod Dev 2003;64(02):219-225

24 Melo APF, Souza WM, Miglino MA. Branches of the intercostal nerves supplyng the diaphragm in dogs. Braz J Morphol Sci 1999; 16(01):61-63

25 de Oliveira HF, de Faria MD, Melo APF, Ferraz RHS. Estudo anatômico sobre a participação dos nervos intercostais na inervação do diafragma em fetos de bovinos azebuados. Vet Not 2001; $7(02): 23-26$ 